\title{
Uniting to Win: What Special Olympics Fandom Can Teach Us
}

Dana Shaker

Scripps College, Class of 2014

\section{Columbus, Ohio}

June $28,2008^{1}$

I watch the swimmers step onto the blocks, a stopwatch in my hand. Each athlete takes his position. Some intently wait to hear the buzzer; others look toward the stands. A spectator waves her hand at one of the athletes and cheers. A few more seconds pass. Then the buzzer sounds. Most competitors dive in, though the athlete in my lane needs a bit more encouragement. I glance to my right at Amber, the other timer in my lane. Rule one of volunteering at Special Olympics Ohio: Never tell an athlete "go" unless you mean it.

Our eyes communicate what we don't need to say. She and I cry "Go, John!" at the top of our lungs and watch him dive in after his competitors. We laugh as water flies onto our faces and clothing from the splash of his start. John takes off down the lane, inching closer to his competitors on the first lap of his 200-meter freestyle.

Modern sport spectators often exist in a liminal space. A story my mother tells about taking me at age three to watch my first local 12-and-under girls' soccer match captures this feeling. Standing comfortably within my mother's arms, I was supposedly mesmerized by the game for the first five minutes. When my mother reached for a water bottle, I instantly broke free and ran onto the field, crying, "Dana's turn! Dana's turn!" Luckily the girls were able to maneuver the ball around me until the referee called a timeout. Albeit brief, my experience as a spectator positioned me between two opposing desires: passively appreciating the home team and actively joining the fun. According to historian Allen Guttmann, many avid sports fans are in fact athletes themselves, as there is a "strong, positive correlation between active and passive sport participation." Via this model we can begin to understand an organization like Special Olympics. Its motto, "Be a Fan," speaks to the power, worth, and necessity of spectators in perpetuating the endeavors of the organization. ${ }^{3}$ The 2008 Swimming Championships of the Special Olympics Ohio Summer Games reminds us of the value of joining in the celebration of the human capacity for excellence, despite possible preconceived notions about competitors with special needs. ${ }^{4}$

1 "Special Olympics Ohio 2008 State Summer Games," Special Olympics Ohio, last modified June 20, 2008, http://www.sooh.org/blog.php?entryID=1403.

${ }^{2}$ Allen Guttmann, Sports: The First Five Millennia (Amherst: University of Massachusetts Press, 2007), 309.

3 "Special Olympics Ohio 2008 State Summer Games."

${ }^{4}$ All subsequent references in the text of this paper to Special Olympics Ohio will be referenced as SOOH. 
To begin investigating why being a fan matters so much to the specific sport and culture of swimming at the $2008 \mathrm{SOOH}$ Summer Games, it is first necessary to know something of both the history and creation of Special Olympics. Growing up with a special needs sister, founder Eunice Kennedy-Shriver recognized very early that the intellectual challenges that precluded her sister from gaining a sense of self-worth in the classroom didn't also need to limit her physical achievement. Believing that sport could equalize the literal and metaphorical playing field for people with special needs, Shriver started a summer day camp in 1962 that used sport to teach "special friends" to develop self-confidence in themselves. ${ }^{5}$ In 1968, Special Olympics held its first international summer games, featuring athletes from the U.S. and Canada. They competed in Track and Field and Swimming. This prompted the U.S. Olympic committee in 1971 to give official approval to the organization to use the word "Olympics" in its name. Even more significantly, the International Olympic Committee officially recognized and endorsed Special Olympics in 1988. Since its founding more than 40 years ago, Special Olympics has grown with unimaginable speed to include three million participants in nearly 200 countries worldwide. International Special Olympics Summer and Winter Games have been hosted by such cities as Dublin, Shanghai, and Athens. ${ }^{6}$ As Kennedy-Shriver herself said, the organization was designed "to bring excellence to our special friends through sports."

Just as important to understanding American spectator and volunteer attitudes toward sport at the SOOH Summer Games in Columbus is the historical context within which these Games took place. Perhaps not since the McCarthy Era had national security, national loyalty, and American national identity felt so unstable. In June 2008, nearly seven years post 9/11, Americans were debating whether wiretapping without warrants was an overreach of federal power or a necessary tool in the new war against terror. They were asking: Were our interrogation techniques brilliantly effective or criminally torturous? Did revised TSA guidelines profile certain ethnic groups or provide better security? And perhaps most relevant to our weekend: Would China, as host of the International Olympic Summer Games that year, validate fears of America's loss of economic power through the sign of athletic dominance? All of these uncertainties provided the contextual backdrop for Special Olympics athletes and volunteers that day in Columbus, as they approached the starting blocks with either swim caps or stopwatches in hand.

And yet my experience that day served as a counter balance to these questions of national and international divisiveness. Rather than feeling awkward and alone, I was welcomed with genuine excitement and goodwill on deck. Volunteers not only supported Special Olympics athletes, but they extended the hand of kindness to one another. Rather than being divided by the competitive impulse to win-be it an ideological debate, global economic superiority, or an

\footnotetext{
${ }^{5}$ Be a Fan of Determination [video]. (2010). Retrieved 3 July, 2011 from http://www.specialolympics.org/video_eks.aspx.

6 "Special Olympics: History," Special Olympics, accessed July 3, 2011, http://www.specialolympics.org/history.aspx.

${ }^{7}$ Be a Fan of Determination.
} 
athletic contest - these people were united in a humanitarian effort to include "our special friends" in sport. On June 28, 2008 in Columbus, I found a community more interested in providing opportunities for the many than in celebrating the victory of one.

As John is making his way down the first lap of his 200 freestyle, I feel a hand tugging the back of my T-shirt. "Is it my turn to swim yet?" asks Candice, an athlete sitting on a chair behind the starting block. I smile. "Not yet, Candice. Once John finishes his 200, it will be your turn.” A grin illuminates her face. She squeals, clapping her hands together.

In the lane next to ours, a coach is speaking to his athlete. "Now, Jane, when you get to the flags, kick as hard as you can. You're going to be great out there. Just remember to have fun." Jane smiles and shakes her head up and down. Candice watches the two intently. Her smile fades.

Amber speaks up. "Don't worry, Candice. You're going to be great, too. It's almost your turn to race now, so get ready!" The words sound similar to what I normally hear at swim meets, but the tone is different. It's truer. More real.

Candice picks up on that unspoken communication. Her smile is back. She fumbles with her goggles and brings them down over her eyes. I laugh. I can't help it. Her enthusiasm is infectious. "That's it, Candice. It'll be your turn soon." She claps and squeals again, jumping up and down in her seat. Smiling to each other, Amber and I turn back to watching John as he paddles into the wall, marking the end of his first 50.

Special Olympics was founded on the assumption that the positive affirmation of spectators provides athletes with the encouragement to build self-confidence in a society whose structure often deprives them of the chance to feel valued. ${ }^{8}$ As an organization, Special Olympics cultivates this spectator relationship by inviting volunteers to help make opportunities available for special needs athletes. ${ }^{9}$ Why the emphasis on spectator and athlete? Guttmann finds this relationship unnecessary, claiming that "sports have existed, do exist, and will continue to exist in situations without an audience." ${ }^{10}$ Is there no inherent value to special needs athletes taking part in sport without an audience? ${ }^{11}$ Obviously there is, as Kennedy-Shriver explained that sport provides a more equal venue to allow special needs athletes to feel that they can be included in and excel at something considered mainstream. ${ }^{12}$ Yet equally important to the building of confidence in special needs athletes is the recognition by other non-special needs people that what these athletes do is valuable. Our own language betrays us in more ways than one. Calling

\footnotetext{
${ }^{8}$ Be a Fan of Determination.

9 “Volunteers," Special Olympics, accessed July 3, 2011, http://www.specialolympics.org/volunteers.aspx.

${ }^{10}$ Guttmann, From Ritual to Record: The Nature of Modern Sports (New York: Columbia University Press, 2004), 12.

${ }^{11}$ Guttmann claims that both "play" and "sport," unlike art, do not require an audience to communicate/have meaning, for there is inherent meaning to the person completing the action. Guttmann, From Ritual to Record, 11-12.

${ }^{12}$ Be a Fan of Determination.
} 
people with special needs "intellectually disabled" is often misconstrued to mean these people are not as capable as others in physical as well as mental capacity. It is our own cultural underpinnings that make the relationship between spectator and sport so crucial for Special Olympics athletes. Without spectator affirmation to combat the negative stereotypes, people who have the capability to excel in athletics may be denied one of the only opportunities in our societal structure that allows them to feel like they can achieve something worth appreciating.

Yet the value of being a fan in Special Olympics presents as many opportunities for spectators to "learn from [our] special friends" as it does for athletes to benefit from their fandom. ${ }^{13}$ Like most other times I have been a spectator at an event, watching Special Olympics athletes race down the pool reawakened the three-year-old in me who wanted to jump in and join the fun. While this is not typically possible, the organization allows its fans to take a handson approach to getting involved in the game through volunteering. ${ }^{14}$ Though I was a timer for the majority of the day, I also helped award each of the athletes medals and ribbons when they stepped onto the podium. I watched other volunteers complete countless jobs, from announcing athlete names, to photographing pictures, to escorting competitors to their events on time. There were even volunteers assigned to cheer for the athletes (though the rest of us were encouraged to cheer for them at every possible moment as well). What those organizers and volunteers did well that summer day in Columbus was to take the spectator's desire to be a part of sport and channel it into opportunities for special needs athletes to compete in a self-affirming environment. ${ }^{15}$ That day, in my mind, the passive spectator became active, perpetuating the invitation to strive that was shown to athletes by coaches, family, and teammates. By applauding athletes, spectators demonstrated their appreciation of both athletes' courage and skill. Veteran spectators understand that, and newbies are quick studies. They're aware that they're not there to watch. They're there to encourage and create.

John is stroking into the wall. This turn marks his second 50. John has been doing well up to this point, but after having caught the leader in the race, he seems to be backing off a bit. I notice, though, that he continues to turn his head to the right when he breathes, always keeping his opponent in view.

The leader picks up the pace. Amber and I turn toward each other. If John keeps going at this speed, he won't be able to make up the time in the last half of the race. As he turns, Amber and I bend down on our knees to cheer him on. He flips and pushes off the wall. Then, water is in my face. I delight to discover the cause: John's feet are moving at lightning speed, kicking water high into the air. His arm tempo has dramatically increased as well. Heading into the far

\footnotetext{
${ }^{13}$ Be a Fan of Determination.

${ }^{14}$ At the games I attended, an exception that allowed special needs and non-special needs athletes to compete together was termed "unified relays" in Track and Field events. Each relay would consist of two Special Olympics athletes and two family members/friends.

${ }^{15}$ As critic Roland Barthes describes in What is Sport?, "[the spectator] is a participant, an actor ..." in viewing the event, so as to experience the meaning of the sport vicariously through the athletes . Roland Barthes, What is Sport?, trans. Richard Howard (New Haven: Yale University Press, 2007), 59-61.
} 
turn, he has decided to close the gap between himself and his competitor. I no sooner process this than Amber grabs my arm. "Did you see that? I can't believe it! He took off, just like he was supposed to!" I am gleeful, too. The elation we both feel over John's race might be lost on nonswimmers. But in the swimming world, the key to winning a 200 is to give it everything you've got in the third 50 .

Sport that is "distanced by the spectacle," as critic Roland Barthes describes, has an ability to convey an idea in all its complexity without being broken or distorted through methods of verbal communication, without losing "its brilliance or its meaning." ${ }^{16} \mathrm{I}$ might not have been able to put that observation into context without watching John in the 2008 Summer Games. The awareness I gained about how a spectator experiences sport became critical to my ability to discern underlying values of sporting events. In comparing the viewing experience of the 2008 SOOH Summer Games with the 2008 Olympic Games in Beijing later that summer, I was struck by how much being a spectator differed between the two organizations. The newscasters at the 2008 Beijing Olympics gave highlights at the bottom of the TV screen saying who won what event in what sport. They reported how many medals each country accumulated, the implication being a country's international power could be expressed at least in part through its number of individual wins. ${ }^{17}$ Likewise, the 2008 SOOH Summer Games had a podium with medals to recognize the winning athletes and a board to display the scores of leading teams. However, each heat of swimmers got a chance on the podium. Every swimmer-who notably had to qualify for his or her event in order to compete-was recognized with a ribbon or a medal. And the board of team scores was tucked away in a corner so as to make it almost invisible.

Obviously there are limits to this comparison. I have never been a live audience member at the Olympic Games, so my experience as an Olympic fan is entirely mediated through American news and sports coverage. But whether the media I have viewed is creating or reflecting the values underpinning Olympic contests, the effect is the same. Only winners, or at least "favorites," receive recognition, leaving the vast number of Olympians anonymous and ignoring the impossible odds they beat just to qualify for their country's team. The message delivered is: Only winning counts. And winning, unfortunately, is part of a dominant discourse on the raison d'être for athletic participation.

A more personal story might flesh out this general conjecture. I normally get dubious looks and shaking heads when I explain the number of hours that I dedicate to my sport while in season. It is reliably around 20-30 hours per week, depending on the team's competition schedule. One friend took the common reaction of incredulity a step further. He first stared at

${ }^{16}$ Barthes, What is Sport?, 61.

${ }^{17}$ As professors Alan Tomlinson and Christopher Young explain, China's approach to the 2008 Olympic Games follows a pattern of countries using the spectacle and global media coverage of the Olympics to assert a nation's international prowess. Alan Tomlinson and Christopher Young, "Culture, Politics, and Spectacle in the Global Sports Event-An Introduction," in National Identity and Global Sports Events: Culture, Politics, and Spectacle in the Olympics and the Football World Cup, ed. Alan Tomlinson and Christopher Young (New York: State University of New York Press, 2006), 2-6. 
me, then said: "But, I don't understand why you do it. I mean, you're not going to go anywhere as a professional athlete. So why would you dedicate so much of your time to it?" Now it was my turn to stare. Is he serious? was the first reaction that popped into my head. He waited patiently for my answer. Not smug, not condescending. Just honestly wanting to know: "Why?"

The irony of it all is that I have "gone places" via my sport: Thailand and Iceland for the International Children's Games; the Ohio High School Division II State Meet. Now, I've come to Claremont to swim for the CMS Athenas. But my friend's words cut me in a deeper place. They said to me, "What you do isn't valuable because you're not an Olympic gold medalist. What you love doesn't matter because it doesn't produce income or further your career." And while clearly this was a singular conversation with only one friend, it echoes a dominant message circulating in our culture that limits the value of sport.

My hope here is not just to compare the role of fans at the two Olympics. Rather, it is to compare the alternative of $\mathrm{SOOH}$ fandom with a more conventional, popular appreciation of athletics in general that mediated sports coverage perpetuates. The Olympics simply serve as a highly visible example. Very few people can make a living as professional athletes. So if amateurs don't always win or can't earn income by playing, why do so many of us participate? Parents often say sports teach children discipline, time management, and team-building skills. But certainly, kids don't stay in a sport for these reasons. I think the poet Emily Dickinson actually gets the athlete's mindset right. "I dwell in possibility" every time I step on a starting block. ${ }^{18}$ Every meet, every event, is a chance to do something great - to hit a turn, to nail a finish, to enjoy racing. Sport teaches us to put our best foot forward at every opportunity, to seize the moment before us. It was this magic possibility for every individual's greatness that touched me at the $2008 \mathrm{SOOH}$ Summer Games.

Arguably, then, even mass-mediated fandom explains something about just how much the conscious spectator can assimilate through viewing sport and sport spectacle. In viewing the marketing campaigns, the focus on nationalistic pride, and what are de facto no-longer-amateur Olympic Games, I believe De Coubertin's original hope that "athletic contests between young people could be a force for international harmony and universal peace" is actually more true of an organization like Special Olympics. ${ }^{19}$ Think of the underpinning assumptions in the film, Chariots of Fire ${ }^{20}$ versus those in the more recent Bend it Like Beckham. ${ }^{21}$ In Chariots of Fire, Abrahams's addiction to win at all costs within the rules dominates a good portion of the film's emotional tension. ${ }^{22}$ In Bend It Like Beckham, Jess's struggle is not to win, but to even be allowed

\footnotetext{
${ }^{18}$ Qtd. in The Norton Anthology of Literature by Women: The Tradition in English, ed. Sandra M. Gilbert and Susan Gubar (New York: W.W. Norton \& Company, 1985), 856.

${ }^{19}$ Tomlinson and Young, "Culture, Politics , and Spectacle," 4-5.

${ }^{20}$ Chariots of Fire, DVD, directed by Hugh Hudson (1981; Century City, CA: Twentieth Century Fox, 2005).

${ }^{21}$ Bend It Like Beckham, DVD, directed by Gurinder Chadha (2002; Century City, CA: Twentieth Century Fox, 2003).

${ }^{22}$ Chariots of Fire.
} 
to play. ${ }^{23}$ This pop-culture reference provides a tidy metaphor for showing the underlying goals of both events: In Chariots (The Olympics) the end goal is to win; in Bend It (Special Olympics) the end goal is to be granted the right to compete. ${ }^{24}$ Both events are valuable; both show spectators different sides of sport. But in viewing how an alternative approach to sport might be structured, how it might work to create an environment where athletes are better supported to do their best, where fans are drawn to become active participants in the athletes' experience, where the goal is to celebrate the human capacity to engage in sport at all, I can't help but wonder: Is there something being a spectator of Special Olympics can teach us about the way modern sport competitions - indeed, all competitions - are approached today?

At the closing ceremony of the 2008 SOOH Summer Games, athletes, their families, and volunteers gather at The Ohio State University's Jessie Owens Stadium. As the closing remarks end, a vocalist takes to the center of the track. With a slow tempo in the background, he begins his first verse with lyrics of friendship and brotherhood, building to a chorus that repeats the words "Everyone Wins." As a life-long athlete, I am conditioned to resist such sentimentalism; only one person takes home the gold, after all. Then I remember John hopping out of the pool after his 200 freestyle earlier that day. He took second, just out-touched by the leader in the race. He exited the water and stood there, huffing and puffing until Candice had already swum a 50 into her 200 freestyle. Amber turned to him. "Are you okay, John?" John threw up his hands and cried, "I lost!" But before either of us could respond, he continued. "But I tried. I tried real hard. And that's all you can do, is try." My heart simultaneously melted and ached as I saw that smile slowly spread across his face. We've all been there as athletes. There are plenty of times you win, and plenty more you don't. But that's not why you compete. "To be brave in the attempt" is key. ${ }^{25}$

Most people have their arms up and are swaying in the bleachers surrounding the stadium. Someone taps my shoulder. As I look over to my right, Amber has her hands up too. She smiles and raises her eyebrows at me. Laughing, I join the wave, synching to the rhythm of becoming one.

${ }^{23}$ Bend It Like Beckham.

${ }^{24}$ Interestingly enough, Timothy Shriver, founder Eunice Kennedy-Shriver's son, casts the discussion of including special needs athletes in terms of rights, and rather specifically "the right to play.” Josh Pate, "Timothy and Anthony Shriver-Eunice’s Legacy,” ABILITY Magazine, August/September 2010, accessed July 1, 2011, http://abilitymagazine.com/Eunice-Legacy.html.

${ }^{25}$ Be a Fan of Determination. 